\title{
Rola inteligencji emocjonalnej jako kompetencji międzykulturowej w osiągnięciu sukcesu zawodowego polskich emigrantów
}

Streszczenie: Inteligencja emocjonalna, jako jedna z ważniejszych kompetencji międzykulturowych, ma istotne znaczenie w kwestii tworzenia dobrych relacji ze swoim otoczeniem i poczuciem spełnienia się w życiu. Wpływając na umiejętność realizacji wyznaczonych sobie celów, jest szczególnie ważnym czynnikiem decydującym o sukcesie zawodowym. Celem badań była próba ukazania związków między jedną z węzłowych kompetencji międzykulturowych, jaką jest „inteligencja emocjonalna" Polaków w Anglii, a ich sukcesem zawodowym. Badania przeprowadzono metodą sondażu diagnostycznego z techniką ankietową. Analizie poddano 114 poprawnie wypełnionych kwestionariuszy, tylko tych osób, które jednoznacznie zadeklarowały osiągnięcie sukcesu zawodowego lub też nie.

Badania wykazały, że we wszystkich szczegółowych kompetencjach składających się na węzłową kompetencję - „inteligencję emocjonalną” takich jak: elastyczność interpersonalna, empatia, radzenie sobie z uczuciami oraz adaptacja i elastyczność zachowań, wyniki na poziomie istotnie wyższym uzyskały osoby badane, które charakteryzowały się poczuciem osiągnięcia sukcesu zawodowego. Zatem można przyjąć, że wysoki poziom przyswojenia powyższych szczegółowych kompetencji stanowi swoistą determinantę sukcesu zawodowego na obczyźnie.

Słowa kluczowe: kompetencje międzykulturowe, inteligencja emocjonalna, edukacja międzykulturowa, emigranci, sukces zawodowy

\section{Wprowadzenie}

Współczesny wysoko zglobalizowany rynek pracy potrzebuje otwartych, wykształconych, mobilnych z odpowiednimi kompetencjami młodych ludzi. W takie tło wpisują się kolejni Polscy emigranci poszukujący swojego miejsca na ziemi. Jednym z takich kierunków, mimo zagrożenia Brexitem, jest w dalszym ciągu Wielka Brytania. Młodzi ludzie z wielkim optymizmem, fantazją i odwagą godną swoich poprzedników włączają się w nurt wielokul- 
turowego rynku pracy. Niesie to za sobą liczne wyzwania, których do końca nie są świadomi. Wyzwania te głównie związane są z nowym środowiskiem kulturowym. Uświadomienie ich następuje dopiero w momencie konfrontacji z odmiennym, różnorodnym otoczeniem kulturowym. Efekty mogą być różne. Jedni świetnie sobie poradzą, osiągając sukces zawodowy, inni nie (Korczyński, 2016). Co zatem decyduje o tym? Wydaje się, że kluczem do osiągnięcia sukcesu zawodowego polskich emigrantów zarobkowych są posiadane przez nich kompetencje, a w szczególności kompetencje międzykulturowe.

Kompetencje od dawna są przedmiotem zainteresowań różnych nauk. Za autora tego terminu we współczesnym znaczeniu uważa się amerykańskiego psychologa Roberta White'a (1959). Aktualnie zainteresowanie tą problematyką nie słabnie. Najczęściej interesują się nią naukowcy z zakresu zarządzania międzykulturowego, edukacji i komunikacji międzykulturowej czy też pedagogiki (Dudzikowa, 1994). Kompetencje w ich ujęciu rozumiane są tradycyjne, jako złożona dyspozycja, stanowiąca wypadkową wiedzy, umiejętności, postaw, motywacji, emocji i wartości.

Tak rozumiane kompetencje stanowią podstawę kompetencji międzykulturowych, tzw. kompetencji miękkich, które najczęściej ujmowane są jako efektywność komunikowania się, zdolność do rozumienia ludzi in n y ch kultur i skuteczność kontaktów z nimi, w celu podejmowania wspólnych aktywności w turbulencyjnym międzykulturowym środowisku pracy (Bogaj i Kwiatkowski, 2001; Gerlach, 2003; Sztompka, 2012). Można je również zdefiniować „jako zbiór cech intelektualnych i osobowościowych pracownika, które używane i rozwijane w warunkach wielokulturowego procesu pracy prowadzą do osiągnięcia rezultatów zgodnych ze strategicznymi zamierzeniami jego samego (pracobiorcy), jak i pracodawcy" (Korczyński, 2016, s.105).

Kompetencje międzykulturowe od dłuższego czasu są przedmiotem licznych badań. Spitzberg i Changton (2009), dokonując metaanalizy tych badań, sporządzili wykaz obejmujący aż 320 pojęć charakteryzujących poszczególne obszary kompetencji międzykulturowych z zakresu wiedzy, umiejętności i postaw/motywacji. Wśród nich znajduje się również inteligencja emocjonalna, która jako jedna z ważniejszych kompetencji międzykulturowych wydaje się podstawą dającą perspektywę osiągnięcia sukcesu zawodowego (por. Goleman, 2007; Korczyński, 2016).

Zdaniem Daniela Golemana (2007) inteligencja emocjonalna to zdolności rozpoznawania przez nas naszych własnych uczuć i uczuć innych, zdol- 
ności motywowania się i kierowania emocjami zarówno naszymi własnymi, jak i osób, z którymi łączą nas jakieś więzi. W pracowniczych grupach zadaniowych wielokulturowego rynku pracy, składającego się z heterogenicznych grup, podstawowym źródłem nieporozumień są najczęściej negatywne emocje związane z różnorodnością, odmiennością w zakresie wartości, pragnień czy też życzeń poszczególnych jej członków (Ayoko i Hartel, 2000). Stan taki może w istotny sposób wywrzeć negatywny wpływ na sprawność działania wielokulturowych zespołów (Pelled, 1996). Zatem można uznać, że inteligencja emocjonalna jest szczególnie ważnym czynnikiem decydującym o sukcesie zawodowym (Goleman, 2007). Istotne zatem wydaje się bycie elastycznym w kontaktach interpersonalnych, czyli wykazywanie się zdolnością do dostosowania się, do zmian i zachowań innych; posiadanie zdolności do odczuwania stanów psychicznych innych osób oraz umiejętności radzenia sobie z własnymi uczuciami.

\section{Założenia badań własnych}

Nawiązując do rozważań zawartych we wstępie, „inteligencję emocjonalną”, jako węzłową międzykulturową kompetencję dla potrzeb badań zdefiniowano jako zdolność do szybkiego zrozumienia i efektywnego działania w kulturze współczesnego wielokulturowego rynku pracy. Inteligencję emocjonalną determinują następujące czynniki: elastyczność interpersonalna, radzenie sobie z uczuciami, adaptacja i elastyczność zachowań oraz empatia. Tak rozumiana „inteligencja emocjonalna”, jako jedna z węzłowych kompetencji międzykulturowych, w połączeniu z innymi kompetencjami stanowić może podstawę zachodzenia procesów adaptacyjnych i przystosowawczych do warunków obcości i wielokulturowości runku pracy (Korczyński, 2016).

W związku z powyższym za cel badań przyjęto próbę ukazania związków między międzykulturowymi kompetencjami - wskaźnikami z zakresu „inteligencji emocjonalnej" Polaków w Anglii, a ich poczuciem sukcesu zawodowego. Główny problem badawczy przybrał formę następującego pytania: Czy istnieją, a jeżeli tak, to jakie są związki między „inteligencją emocjonalną” Polaków w Anglii a ich poczuciem sukcesu zawodowego? Uszczegółowiono go jeszcze poprzez następujące pytania-problemy:

1. Jaki jest poziom przyswojenia szczegółowych kompetencji (wskaźników) z zakresu „inteligencji emocjonalnej” przez badanych Polaków?

2. Jakie jest subiektywne poczucie sukcesu zawodowego badanych Polaków? 
3. Jakie są związki miedzy szczegółowymi międzykulturowymi kompetencjami (wskaźnikami) z zakresu „inteligencji emocjonalnej” Polaków w Anglii a ich poczuciem sukcesu zawodowego?

Przyjęto następującą hipotezę: Zachodzą istotne związki między „inteligencją emocjonalną", jako węzłową międzykulturową kompetencją Polaków w Anglii, a ich sukcesem zawodowym. Osoby badane, które uzyskują wysoki poziom przyswojenia takich szczegółowych kompetencji jak: elastyczność interpersonalna, radzenie sobie z uczuciami, adaptacja $i$ elastyczność zachowań oraz empatia, zdecydowanie częściej mają poczucie osiągnięcia sukcesu zawodowego. Za zmienną zależną przyjęto i międzykulturową kompetencję „inteligencję emocjonalną", a w szczególności jej wskaźniki, a zmienną niezależną - subiektywną ocenę sukcesu zawodowego.

Prezentowane badania realizowane były w ramach projektu badawczego Zakładu Edukacji Międzykulturowej, Instytutu Pedagogiki, Wydziału Pedagogiki i Psychologii UMCS w Lublinie. Przeprowadzono je z wykorzystaniem metody sondażu diagnostycznego, z techniką ankietową oraz narzędziem badawczym w postaci kwestionariusza ankiety własnej konstrukcji. Skonstruowano go, opierając się na opinii sędziów kompetentnych z Polski i Anglii, wybierając 25 najbardziej istotnych i aktualnych kompetencji międzykulturowych z listy obejmującej 320 pojęć charakteryzujących szczegółowe kompetencje międzykulturowe z zakresu wiedzy, umiejętności i postaw opracowanej przez Briana H. Spitzberga i Gabrielle Changnon (2009). Wśród nich znalazły się cztery szczegółowe kompetencje międzykulturowe, które zgodnie z sugestią Shannon L. Lloyd oraz Charmine E. J. Härtel (za: Mazur, 2012), również opierając się na opinii sędziów kompetentnych, zakwalifikowano do jednej z 6 węzłowych kompetencji międzykulturowych „inteligencji emocjonalnej" (tabela 1) (Korczyński, 2016).

Tabela 1. Węzłowa kompetencja międzykulturowa - „inteligencja emocjonalna” i jej kompetencje szczegółowe (wskaźniki)

\begin{tabular}{|l|l|}
\hline \multicolumn{1}{|c|}{ Węzłowa kompetencja międzykulturowa } & \multicolumn{1}{|c|}{ Szczegółowe kompetencje (wskaźniki) } \\
\hline „Inteligencja emocjonalna” & $\begin{array}{l}\text { elastyczność interpersonalna } \\
\text { empatia } \\
\text { radzenie sobie z uczuciami } \\
\text { adaptacja i elastyczność zachowań }\end{array}$ \\
\hline
\end{tabular}

Źródło: badania własne.

Dla potrzeb badań własnych przyjęto następujące rozumienie przedstawionych w tabeli 1 wskaźników węzłowej kompetencji „inteligencja emocjonalna”: 
Elastyczność interpersonalna - to zdolność do dostosowania się do zachowań innych; Empatia - to zdolność wczuwania się w uczucia i potrzeby innych; Radzenie sobie z uczuciami - to zdolność do radzenia sobie ze swoją złością, poczuciem osamotnienia, gniewem, smutkiem, bezradnością czy lękiem; Adaptacja i elastyczność zachowań - to zdolność przystosowywania się do zmian.

W kwestionariuszu zamieszczono m.in. pytanie o poziom ich przyswojenia, wyposażając je w kafeterię odpowiedzi w postaci pięciostopniowej skali Likerta. Dzięki temu uzyskano możliwość ustalenia poziomów uzyskanych wyników: niski - wyniki: 1,00-2,15; przeciętny - wyniki: 2,16$-3,75$ i wysoki - wyniki: 3,76-5,0.

Badania zrealizowano w południowo-zachodniej części Anglii. Narzędzia badawcze rozprowadzono (losowo) poprzez portale społecznościowe oraz wręczając osobiście, dzięki uprzejmości pracowników firmy zatrudniającej na lokalnym rynku pracy - Mploy Staffing Solutions w Dorchester i Pool, Hrabstwo Dorset.

Analizę zebranego materiału badawczego w zakresie poszukiwania związków między poziomem przyswojenia poszczególnych wskaźników międzykulturowej kompetencji „inteligencja emocjonalna” a subiektywnym poczuciem sukcesu zawodowego dokonano z wykorzystaniem testu t-Studenta. Przebadano ogółem 311 osób, z czego do analiz zakwalifikowano 193 kwestionariusze. W niniejszych badaniach wykorzystano 114 - tych osób, które jednoznacznie zadeklarowały osiągnięcie sukcesu zawodowego (TAK) lub też (NIE). Celowo pominięto w analizie osoby badane, które nie były zdecydowane co do swojego sukcesu zawodowego (Trudno powiedzieć). Wyselekcjonowana grupa nie spełnia wymogów reprezentatywności.

\section{Wyniki badań}

Graficzną wizualizację danych charakteryzujących badane osoby z uwzględnieniem deklaracji sukcesu zawodowego, w rozbiciu na TAK i NIE, przedstawiono w tabeli 2.

Tabela 2. Dane demograficzno-społeczne badanych osób

\begin{tabular}{|l|l|r|r|r|r|r|r|}
\hline \multicolumn{2}{|c|}{$N$} & \multicolumn{2}{c|}{ TAK } & \multicolumn{2}{c|}{ NIE } & \multicolumn{2}{c|}{ RAZEM } \\
\cline { 3 - 10 } \multicolumn{2}{|c|}{114} & $\%$ & $\mathrm{~N}$ & $\%$ & $\mathrm{~N} 156$ & $\% 100$ & \\
\hline \multirow{2}{*}{ Płeć } & 73,0 & 42 & 27,0 & & & \\
\hline
\end{tabular}




\begin{tabular}{|c|c|c|c|c|c|c|c|}
\hline \multirow{2}{*}{ Zatrudnienie } & stałe & 94 & 60,0 & 16 & 10,5 & 110 & 70,5 \\
\hline & tymczasowe & 20 & 13,0 & 26 & 16,5 & 46 & 29,5 \\
\hline \multirow{3}{*}{ Zamiar pozostania w Anglii } & tak & 80 & 51,0 & 16 & 10,5 & 96 & 61,5 \\
\hline & nie mam zdania & 8 & 5,0 & 20 & 13,0 & 28 & 18,0 \\
\hline & nie & 26 & 17,0 & 6 & 3,5 & 32 & 20,5 \\
\hline \multirow{3}{*}{ Wykształcenie } & wyższe & 48 & 31,0 & 26 & 16,5 & 74 & 47,5 \\
\hline & średnie & 66 & 42,0 & 14 & 9,0 & 80 & 51,0 \\
\hline & zawodowe & 0 & 0,0 & 2 & 1,5 & 2 & 1,5 \\
\hline \multirow{2}{*}{ Wykonywany zawód } & p. umysłowy & 70 & 45,0 & 0 & 0,0 & 70 & 45,0 \\
\hline & p. fizyczny & 44 & 28,0 & 42 & 27,0 & 86 & 55,0 \\
\hline \multirow{3}{*}{$\begin{array}{l}\text { Wyniki ukończenia studiów/ } \\
\text { szkoły }\end{array}$} & b. dobry & 30 & 19,0 & 0 & 0,0 & 30 & 19,0 \\
\hline & bobry & 66 & 42,0 & 32 & 21,0 & 98 & 63,0 \\
\hline & dostateczny & 18 & 12,0 & 10 & 6,0 & 28 & 18,0 \\
\hline \multirow{3}{*}{$\begin{array}{l}\text { Zgodność wykonywanej pracy } \\
\text { z wykształceniem }\end{array}$} & tak & 34 & 23,0 & 0 & 0,0 & 34 & 23,0 \\
\hline & trudno powiedzieć & 6 & 3,5 & 0 & 0,0 & 6 & 3,5 \\
\hline & nie & 74 & 46,5 & 42 & 27,0 & 116 & 73,5 \\
\hline \multirow{5}{*}{$\begin{array}{l}\text { Znajomość języka angielskie- } \\
\text { go }\end{array}$} & b. dobra & 66 & 42,0 & 0 & 0,0 & 66 & 42,0 \\
\hline & dobra & 36 & 23,5 & 8 & 5,0 & 44 & 28,5 \\
\hline & przeciętna & 12 & 7,5 & 22 & 14,0 & 34 & 21,5 \\
\hline & słaba & 0 & 0,0 & 6 & 4,0 & 6 & 4,0 \\
\hline & b. słaba & 0 & 0,0 & 6 & 4,0 & 6 & 4,0 \\
\hline
\end{tabular}

Źródło: badania własne.

Wszystkie osoby w chwili badania pracowały w Anglii minimum 5 lat. Ich wiek zawierał się w przedziale od 26 do 49 lat. Wśród przebadanych kobiety stanowiły - 53,0\% (z czego 40\% deklarowało sukces zawodowy TAK, a 13\% NIE), a mężczyźni - 47,0\% (z czego 33\% - TAK, a 14\% - NIE). W większości byli oni zatrudnieni na czas stały - 70,5\% (w tym 60\% -TAK, 10,5 - NIE). Zamiar pozostania na stałe w Anglii deklarowało ogółem 61,5\%, z czego 51,0\% stanowili badani uważający, że osiągnęli sukces zawodowy.

Wśród badanych osób deklarujących osiągniecie sukcesu zawodowego dominują nieznacznie osoby z wykształceniem średnim - 42,0\% i wyższym - 31,0\%, natomiast wśród osób uważających, że nie osiągnęły sukcesu zawodowego - odpowiednio 9,0\% i 16,5\%. Pracują oni głównie, jako pracownicy fizyczni - 55,0\%. Rozkład procentowy w tym obszarze pomiędzy TAK i NIE jest w miarę równomierny $28,0 \%$ i 27,0\%. Natomiast, jako pracownicy umysłowi występują tylko osoby deklarujące osiągniecie sukcesu zawodowego - 45,0\%. Zdecydowana większość - 73,0\% deklarowała brak zgodności wykonywanej pracy z wykształceniem (46,5\% - TAK, 27,0\% - NIE, czyli wszyscy). Zgodność taką potwierdziło ogółem 23,0\% badanych, tylko ci, którzy osiągnęli sukces zawodowy. Oceny, z jakimi badani ukończyli naukę, to 
bardzo dobry - 19,0\% - uzyskali tylko ci, którzy uważają, że osiągnęli sukces zawodowy, dobry - 63,0\% (w tym 42,0\% - TAK, 21,0\% - NIE) dostateczny - 18,0\% (w tym 12,0\% - TAK, 6,0\% - NIE). Znajomość języka angielskiego na poziomie bardzo dobrym wskazało $42,0 \%$, wszyscy z grupy deklarującej sukces zawodowy, dobrym - 28,5\% (w tym 23,5\% - TAK, 5,0\% - NIE), przeciętnym - 21,5\% (w tym 7,5\% - TAK, 14,0\% - NIE), słabym i bardzo słabym $-8,0 \%$ tylko w grupie osób NIE (por. tabela 2).

Poziom przyswojenia szczegółowych kompetencji - wskaźników węzłowej kompetencji „inteligencja emocjonalna” w opinii osób badanych można uznać za zadowalający (por. wykres 1). Z czterech wskaźników trzy, tj. elastyczność interpersonalna $(4,19)$, radzenie sobie z uczuciami $(4,13)$ oraz adaptacja $i$ elastyczność zachowań $(4,18)$ uzyskały wyniki wysokie. Tylko $\mathrm{w}$ jednym, tj. empatia $(3,69)$ - niskie, ale z tendencją ku wysokim.

Wykres 1. Poziom przyswojenia szczegółowych kompetencji (wskaźników) z zakresu „inteligencji emocjonalnej” badanych osób



Źródło: badania własne.

Natomiast poczucie sukcesu zawodowego w opinii badanych Polaków jest dosyć zróżnicowane (tabela 3). Osiągnięcie sukcesu zawodowego deklaruje $73,1 \%$, z kolei jego brak - pozostali w liczbie $26,9 \%$. 
Tabela 3. Poczucie sukcesu zawodowego w opinii badanych osób

\begin{tabular}{|l|c|c|}
\hline \multicolumn{1}{|c|}{ Sukces zawodowy } & N & $\%$ \\
\hline TAK & 57 & 73,1 \\
\hline NIE & 21 & 26,9 \\
\hline RAZEM & 78 & 100 \\
\hline
\end{tabular}

Źródło: badania własne.

Poszukując odpowiedzi na zasadnicze pytanie problematyki badawczej dokonano wizualizacji uzyskanych wyników badań (por. wykresy 2-5, tabela 4). Z ich analizy wynika, że badane osoby, które uważają, że osiągnęły sukces zawodowy (TAK), uzyskują wyraźnie wyższe wyniki średnie w zakresie wszystkich analizowanych wskaźników „inteligencji emocjonalnej”. Ich wyniki mieszczą się w zakresie wyników wysokich, prezentując wysoki poziom przyswojenia analizowanych wskaźników. Natomiast badane osoby, które zadeklarowały brak poczucia sukcesu zawodowego (NIE), uzyskały zdecydowanie niższe wyniki średnie poszczególnych wskaźników, świadczące w zasadzie o przeciętnym poziomie przyswojenia sobie tych kompetencji.

Wykres 2. Poziom przyswojenia wskaźników kompetencji „inteligencja emocjonalna” a poczucie sukcesu zawodowego badanych osób (TAK, NIE)

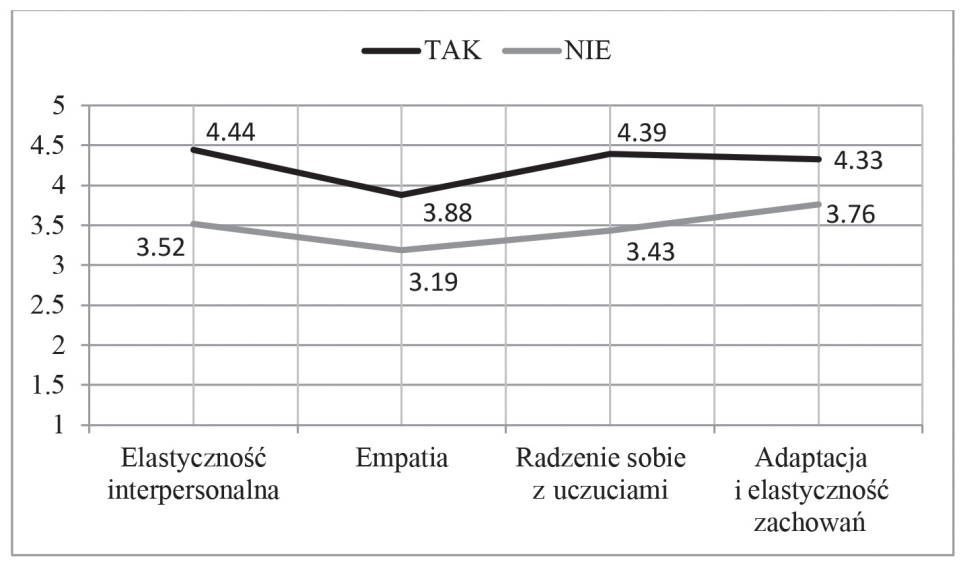

Źródło: badania własne.

Potwierdzeniem powyższych spostrzeżeń są wyniki uzyskane z ich porównania, z wykorzystaniem testu t-Studenta (por. tabela 4). We wszystkich analizowanych przypadkach różnice w zakresie wyników średnich poszczególnych wskaźników są istotne statystycznie $(\mathrm{p}<0,05)$. 
Tabela 4. Wskaźniki „inteligencji emocjonalnej” a poczucie sukcesu zawodowego badanych Polaków

\begin{tabular}{|c|c|c|c|c|c|c|}
\hline \multirow{3}{*}{$\begin{array}{c}\text { WSKAŹNIKI } \\
\text { „inteligencja emocjonalna” }\end{array}$} & \multicolumn{4}{|c|}{ SUKCES ZAWODOWY } & \multirow{2}{*}{\multicolumn{2}{|c|}{$\begin{array}{l}\text { Porównanie } \\
\text { średnich }\end{array}$}} \\
\hline & \multicolumn{2}{|c|}{ TAK } & \multicolumn{2}{|c|}{ NIE } & & \\
\hline & M & SD & M & $\mathrm{SD}$ & $t^{\circ}$ & $\mathrm{p}$ \\
\hline Efektywność interpersonalna & 4,44 & 0,62 & 3,52 & 0,74 & 0,62 & 0,00 \\
\hline Empatia & 3,88 & 1,05 & 3,19 & 0,74 & 1,05 & 0,00 \\
\hline Radzenie sobie z uczuciami & 4,39 & 0,75 & 3,43 & 1,12 & 0,75 & 0,00 \\
\hline Adaptacja i elastyczność zachowań & 4,33 & 0,69 & 3,76 & 0,88 & 0,69 & 0,00 \\
\hline
\end{tabular}

Wyniki istotne statystycznie dla $\mathrm{p} \leq 0,05$

Źródło: badania własne.

Szczegółowa analiza z wykorzystaniem wykresów ramka wąsy (por. wykresy 3-5) dodatkowo ujawnia zdecydowanie większy związek sukcesu zawodowego z poziomem przyswojenia poszczególnych szczegółowych kompetencji międzykulturowych wchodzących w skład „inteligencji emocjonalnej”.

W przypadku pierwszej z analizowanych szczegółowych kompetencji efektywność interpersonalna, badani Polacy, którzy zadeklarowali osiągnięcie sukcesu zawodowego w zdecydowanej większości, bo aż w ponad 75\%, przyswoili ją na poziomie wysokim, pozostali, przeciętnym. Żaden z nich nie uzyskał wyników na poziomie niskim. Natomiast badani, którzy nie osiągnęli sukcesu zawodowego, w ponad 50\% uzyskali wprawdzie wyniki wysokie, ale $\mathrm{z}$ tendencją ku przeciętnym. Znalazły się wśród nich także osoby, które uzyskały w zakresie analizowanej kompetencji wyniki na poziomie niskim. Na uwagę zasługuje duża jednorodność w zakresie deklarowanych wyników.

Wykres 3. Efektywność interpersonalna a poczucie sukcesu zawodowego badanych osób

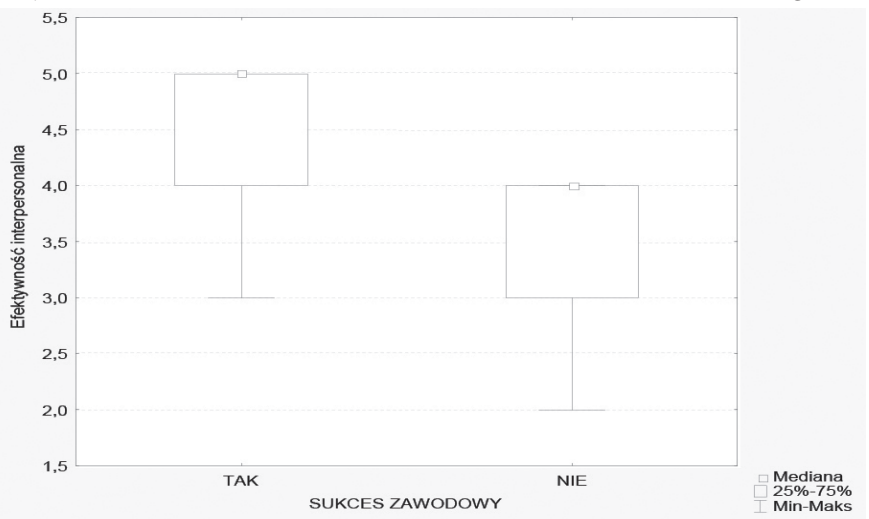

Źródło: badania własne. 
Trochę inaczej przedstawia się sytuacja w zakresie kompetencji szczegółowej empatia (por. wykres 4). Grupa badanych osób deklarujących sukces zawodowy wprawdzie uzyskuje wynik średni w przedziale wyników wysokich, ale jest on najniższy ze wszystkich analizowanych wskaźników. Również odchylenie standardowe różni się znacznie. Przełożyło się to na inne miary statystyczne, z analizy których wynika, że badani Polacy na TAK w przeszło $50 \%$ uzyskali wyniki wysokie, gdy analogicznie badani na NIE tylko w $25 \%$. Jednak grupa osiągająca sukces zawodowy nie jest już tak spójna w swojej ocenie. Znajdują się w niej osoby, które uzyskały wyniki przeciętne i niskie czego w zasadzie nie można zaobserwować w grupie badanych osób, którzy nie deklarują osiągnięcia sukcesu zawodowego.

Wykres 4. Empatia a poczucie sukcesu zawodowego badanych osób

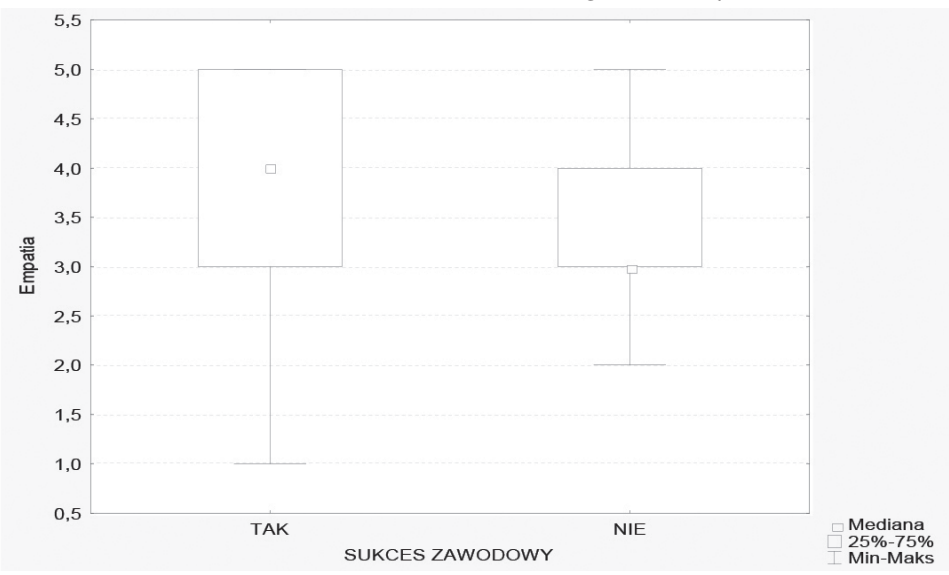

Źródło: badania własne.

Jeszcze inaczej sytuacja przedstawia się w przypadku wskaźnika radzenie sobie z uczuciami (wykres 5). Badane osoby deklarujące sukces zawodowy uzyskują zdecydowanie wyższe wyniki we wszystkich analizowanych miarach (średnia, odchylenie standardowe, mediana, kwartale) od grupy badanych nieuzyskujących sukcesu zawodowego. Wynika z tego, że żadna badana osoba z grupy TAK nie uzyskała wyników niskich, a ponad 75\% badanych uzyskało wyniki na poziomie wysokim, wykazując bardzo dobre przyswojenie analizowanej kompetencji. Inaczej sytuacja przedstawia się w grupie NIE. Tylko $25 \%$ badanych uzyskuje wyniki wysokie, a pozostałych $75 \%$ - uzyskuje głównie wyniki przeciętne, ale zdarzają się również niskie. 
Wykres 5. Radzenie sobie z uczuciami a poczucie sukcesu zawodowego badanych osób

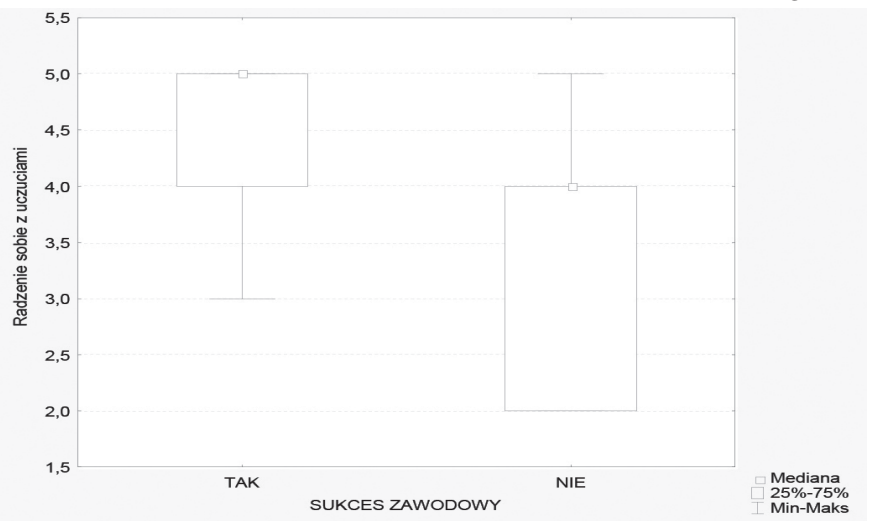

Źródło: badania własne.

Wykres 6. Adaptacja i elastyczność zachowań a poczucie sukcesu zawodowego badanych osób



Źródło: badania własne.

Ostatnia z analizowanych szczegółowych kompetencji - adaptacja i elastyczność zachowań (por. wykres 6) w pełni potwierdza wyniki testu t-Studenta. Również i w tym przypadku wszystkie analizowane miary uplasowały się na wyższym poziomie w grupie badanych Polaków deklarujących sukces zawodowy niż niedeklarujących go. Świadczy o tym m.in. fakt, że przeszło $75 \%$ badanych, będących na TAK przyswoiło sobie analizowaną kompetencję na poziomie wysokim. Pozostałe osoby deklarują ją głównie na poziomie przeciętnym. W grupie drugiej, niedeklarującej osiągnięcia sukcesu zawodowego, aż 50\% 
badanych wykazuje się tylko przeciętnym poziomem przyswojenia kompetencji adaptacja i elastyczność zachowań. Pozostali przyswoili tę kompetencję na tym samym lub wyższym poziomie.

\section{Podsumowanie i wnioski}

Badania jednoznacznie wykazały, że sukces zawodowy w kategoriach TAK, NIE, istotnie różnicuje $(\mathrm{p}<0,05)$ wszystkie cztery szczegółowe kompetencje wskaźniki (efektywność interpersonalna, empatia, radzenie sobie z uczuciami, adaptacja i elastyczność zachowań) węzłowej kompetencji międzykulturowej - „inteligencji emocjonalnej”. Badani Polacy deklarujący osiągnięcie sukcesu zawodowego uzyskali zdecydowanie wyższe wyniki (wszystkie na poziomie wysokim) od tych, którzy takiego sukcesu nie odczuwają (wszystkie na poziomie przeciętnym). Zatem można powiedzieć, że to osoby badane, które osiągnęły sukces zawodowy, przejawiają zdecydowanie na wyższym poziomie zdolność dostosowania się do nowych warunków pracy, do zachowań innych kulturowo współpracowników; zdecydowanie lepiej również wczuwają się w uczucia i potrzeby innych; ponadto lepiej radzą sobie ze swoją złością, poczuciem osamotnienia, gniewem, smutkiem, bezradnością czy też lękiem; wykazują lepszą zdolność do przystosowywania się do zmian od osób, które sukcesu zawodowego nie osiągnęły.

Ponadto analiza danych demograficzno-społecznych wykazała, że osoby badane deklarujące osiągnięcie sukcesu zawodowego mające na wyższym poziomie przyswojone szczegółowe kompetencje z zakresu „inteligencji emocjonalnej" zdecydowanie częściej pracują jako pracownicy stali niż tymczasowi; deklarują w większości chęć pozostania na stałe w Anglii; legitymują się wykształceniem średnim i wyższym; w zdecydowanej większości pracują jako pracownicy umysłowi; ukończyli szkoły, studia głównie z oceną bardzo dobrą i dobrą; znaczna grupa spośród nich pracuje zgodnie z uzyskanymi kwalifikacjami; deklarują głównie bardzo dobrą i dobrą znajomość języka angielskiego. Inaczej sytuacja przedstawia się u osób, które nie osiągnęły sukcesu zawodowego. Większość z nich pracuje jako pracownicy tymczasowi, żaden z badanych nie pracuje w wyuczonym zawodzie, wszyscy pracują jako pracownicy fizyczni, znajomość języka angielskiego mają na poziomie przeciętnym.

Powyższe badania potwierdzają w pełni przyjętą hipotezę. Uświadamiają również ważność inteligencji emocjonalnej, jako jednego z najistotniejszych determinantów sukcesu nie tylko zawodowego. Człowiek inteligentny emocjonalnie jest otwarty na nowe doświadczenia, łatwo nawiązuje kontakty 
z innymi ludźmi, potrafi okazywać uczucia adekwatnie do sytuacji, dobrze radzi sobie z nimi, potrafi odmawiać, realistycznie ocenia osiągnięcia swoje i innych, nie boi się krytyki i ryzyka. Inteligencja emocjonalna ma decydujące znaczenie w poczuciu spełniania się w życiu i pracy zawodowej (Goleman, 2007; Tomczyk, 2014).

$\mathrm{Na}$ drugim biegunie inteligencji emocjonalnej znajduje się niedostatek emocjonalny. Może on prowadzić do istotnych trudności w funkcjonowaniu społecznym, takich jak zmniejszenie się poziomu satysfakcji życiowej i zawodowej oraz umiejętności tworzenia dobrych relacji z innymi ludźmi. W szczególności wyrażać się to może frustracją, ciągłym zmęczeniem, przewlekłym stresem, wypaleniem zawodowym, mniejszą wydajnością pracy, rozdrażnieniem, gniewem, agresją, popadaniem w uzależnienia czy depresję.

Bardzo istotne jest zatem wyposażanie młodych ludzi wchodzących na wielokulturowe rynki pracy w odpowiednie kompetencje międzykulturowe, w tym przypadku - inteligencję emocjonalną. Wydaje się, że największy wysiłek w kształtowaniu tej kompetencji powinien być zaakcentowany w okresie wczesnej socjalizacji. Nie bez znaczenia jest również okres edukacji szkolnej niezależnie od jego poziomu. Bowiem każdy etap edukacji zakłada wyposażanie swojego absolwenta w odpowiednie kompetencje. Zwiększanie zaś poziomu inteligencji emocjonalnej istotnie oddziałuje na jakość naszego życia zarówno rodzinnego, jak i zawodowego. Zatem powinniśmy zastanowić się nad wprowadzeniem konkretnych zapisów do zakładanych efektów kształcenia na wszystkich poziomach i kierunkach studiów. Tam gdzie jest to możliwe, należałoby uzupełnić programy kształcenia o przedmiot „Kompetencje międzykulturowe”. W efekcie nasi absolwenci powinni zostać wyposażeni w kompetencje dające im możliwość skutecznego konkurowania na współczesnym wielokulturowym rynku pracy zarówno na emigracji, jak i w kraju.

\section{Bibliografia}

Ayoko, O. B. and Hartel, C. E. J. 2000. Cultural differences at work: How managers deepen and lessen the cross-racial divide in their workgroups. Queensland Review. 7, pp.77-87.

Bogaj, A. i Kwiatkowski, S. M. red. 2001. Szkoła a rynek pracy. Podręcznik akademicki. Warszawa: PWN.

Bolten, J. 2006. Interkulturowa kompetencja. Poznań: UAM.

Chen, G. M. and Starosta, W. J. 1996. Intercultural communication com- 
petence: A synthesis. In: Burleson, B. ed. Communication Yearbook 19. Thousand Oaks: Sage, pp. 353-383.

Dudzikowa, M. 1994. Kompetencje autokreacyjne - czy i jak są możliwe do nabycia w toku studiów pedagogicznych. W: Kwiatkowska, H. red. Ewolucja tożsamości pedagogiki. Warszawa: PTP, ss. 198-215.

Dylak, S. 1995. Wizualizacja w kształceniu nauczycieli. Poznań: UAM.

Gerlach, R. 2003. Edukacja zawodowa nie tylko dla rynku pracy. W: Gerlach, R. red. Edukacja wobec rynku pracy. Realia - możliwości - perspektywy. Bydgoszcz: Wydawnictwo Akademii Bydgoskiej im. Kazimierza Wielkiego, ss. $171-179$.

Goleman, D. 2007. Inteligencja emocjonalna. Poznań: Rebis.

Korczyński, M. 2016. Międzykulturowe kompetencje pracobiorców wielokulturowego rynku pracy w opinii polskich pracowników firm angielskich. Journal of Modern Science. 3 (30), ss. 217-232.

Kwiatkowski, S. M. i Symela, K. 2001. Standardy kwalifikacji zawodowych. Teoria. Metodologia. Projekty. Warszawa: IBE.

Magala, S. 2011. Kompetencje międzykulturowe. Warszawa: Wolters Kluwer. Mazur, B. 2012. Kompetencje międzykulturowe w opinii podlaskich menedżerów. Współczesne Zarządzanie. 1, ss.182-191.

Mikułowski-Pomorski, J. 2007. Jak narody porozumiewaja się ze sobq w komunikacji międzykulturowej i komunikowaniu medialnym. Kraków: Universitas.

Nikitorowicz, J., Sobecki, M., Danilewicz, W., Muszyńska J., Misiejuk D. i Bajkowski, T. 2013. Kompetencje do komunikacji międzykulturowej $w$ aspekcie wielokulturowości regionów i procesów migracyjnych. Warszawa: Wydawnictwo Akademickie „Żak”.

Pelled, L. H. 1996. Demographic diversity, conflict and work group outcomes: An intervening process theory. Organization Science. 7 (6), pp. 615-631. Spitzbergd, B. H. and Changnon, G. 2009. Conceptualizating intercultural competence. W: Deardorff, D. K. ed. Intercultural Competence. Los Angeles, London, New Delhi, Singapore, Washington: Sage Publ., pp. 2-52. Sztompka, P. 2012. Socjologia. Analiza społeczeństwa. Kraków: Społeczny Instytut Wydawniczy Znak.

Tomczyk, J. 2014. Inteligencja emocjonalna. Jak panować nad uczuciami. Warszawa: Edgard. 


\title{
Emotional intelligence as an intercultural competence in professional success of Polish immigrants
}

\begin{abstract}
Emotional intelligence, as one of the most important intercultural competences, is of major importance for the issue of establishing good relations with the individual's own environment and for the sense of achievement. As it influences the ability to fulfil the established goals, it becomes a very important factor when deciding about professional success. The aim of the study was an attempt to show relations between one of the key intercultural competences - the "emotional intelligence" of Poles living in England, as well as their professional success. The study was conducted with the use of the method of diagnostic survey and the questionnaire technique. 114 correctly filled questionnaires only of those respondents who clearly declared whether they had achieved professional success or not were subjected to the analysis.

The study showed that the people characterised by a sense of professional achievement had obtained significantly higher results concerning the acquisition of all the skills constituting the key competence of "emotional intelligence", such as: interpersonal flexibility, empathy, the ability to cope with feelings and adaptation and flexibility of behaviour. Thus, it can be concluded that a high level of acquiring these skills constitutes a specific determinant of professional success achieved in a foreign country.
\end{abstract}

Keywords: intercultural competences, emotional intelligence, intercultural education, immigrants, professional success

Translated by Katarzyna Mieszkowska 